\title{
Evaluating Management Alternatives with a Beef Production Systems Model
}

\author{
M.M. KOTHMANN AND GERALD M. SMITH
}

\author{
Abstract
}

Simulation techniques were utilized to study alternative management practices for cow-calf operations in the Coastal Prairie of Texas. Data obtained over a 6-year period from a cooperating ranch were used to validate a beef production model successfully. Management practices evaluated with the model included fall, winter, spring, and split (fall-spring) calving seasons, July 1 and October 1 weaning dates, and two levels of nutrition. Eight combinations of these practices were simulated. Winter calving increased death losses of calves compared to fall and spring at the base nutritional level. Fall calving increased weaning weights, whereas spring calving increased the present calf crop. Fall calving with improved nutrtion resulted in the highest level of calf production. Resource limitations frequently prevent screening many management combinations by field research techniques. Simulation can be a valuable aid for integrating and extending experimental data and for selecting the most promising combinations of practices for field testing.

Range livestock production in the Coastal Prairie of Texas is characterized by high potential, but also by many difficulties. High rainfall and long growing seasons result in high potential forage production, but environmental and nutritional stresses on livestock are great during winter months. Cow-calf producers must cope with the effects of low levels of digestible energy and protein in the forage during the winter that result in low calf crop percentages, high death losses of young calves and severe weight losses by cows. Management alternatives such as dates of calving and weaning and kinds and amounts of supplements all have significant impact on the productivity of a ranch. However, evaluation of all possible management combinations in a field research program is not possible.

Computer simulation is a tool which makes possible the evaluation of many combinations of management practices. A Beef Cattle Production Systems Model developed at Texas A\&M University (Sanders and Cartwright 1979a, b) was used to evaluate several combinations of management practices for cow-calf operation. Forage and cattle production data obtained over a 6-year period from a cooperating ranch in the Coastal Prairie of Texas were used to estimate base parameters as well as to validate the model. The objectives of this study were to simulate accurately, production from a cow-calf operation and to demonstrate the value of simulation as a research tool.

\section{Materials and Methods}

\section{Study Area}

Livestock and forage data for the simulations were obtained from a cooperating ranch in northern Calhoun County. The average frost-free period is from mid-February to mid-December and

Authors are professor, Department of Range Science, and visiting associate professor, Department of Animal Science, Texas A\&M University.

This report is Technical Article No. 16751 from the Texas Agricultural Experiment Station. The authors express their appreciation to Mr. R.T. Hinnant and Dr. C.R. Long for assistance in collecting portions of the data and to Dr. T.C. Cartwright for his helpful suggestions during the preparation of the manuscript.

Manuscript received August 24, 1981. the average annual rainfall is about $114 \mathrm{~cm}(45 \mathrm{in})$. Native vegetation is typical of Tall Grass prairie, but has been invaded by Macartney rose (Rosa bracteata). Little bluestem (Schizachyrium scoparium) is the dominant grass species with yellow indiangrass (Sorghastrum nutans) and various species of paspalum (Paspalum spp.) as subdominants. Durham and Kothmann (1977) gave a more detailed description of the vegetation on the study area.

Elevation is about $6 \mathrm{~m}$ above sea level and drainage is poor. Soils are heavy dark clays of the Lake Charles and Victoria series. Following heavy rains, water stands on much of the soil surface for several days. During January and early February there was generally standing water on much of this ranch.

The ranch was operated as a cow-calf operation with calves sold or moved to other locations at weaning. The herd of approximately 2000 grade Santa Gertrudis cows was rotated between rangeland and Coastal bermudagrass but generally spent the entire period from November to April on rangeland. Yearling replacement heifers were grazed on oat pasture from November to April, with the stocking rate set at a level which restricted forage availability to the point that intake was limited. The primary winter supplement was Coastal bermudagrass hay which averaged about $6 \%$ crude protein (CP) and $45 \%$ digestible organic matter. Mineral blocks containing $12 \% \mathrm{P}$ and $12 \% \mathrm{Ca}$ plus trace minerals were provided free choice throughout the year.

\section{Simulation}

Simulation was conducted using a dynamic computer model (Sanders 1974, 1979; Sanders and Cartwright 1979a,b) that was modified to keep account of individual animals (Baker 1982). The model predicts growth rates, condition, milk production, fertility, and deaths from the genetic potential of the cattle interacting with the quality and availability of feed resources. Breedtype for size, maturing pattern, and milk production potential plus time and length of calving season, culling and selling policies, supplemental feeding, and forage quality and availability were set in the model.

The model was based on the assumption that genetic potential for three predominant characters of cattle account for a large proportion of the performance or productivity differences on a life-cycle basis: (1) mature size, (2) milk production, and (3) maturing rate. Effects of previous nutrition were accounted for by the deviation of an animal's present weight (W) from its structural size (WM); WM was the weight of an animal in good condition (3\% body fat at birth; $25 \%$ at maturity). The growth curve for structural size specified the genetic potential for mature size (WMA) and rate of increase in WM. An animal's nutrient intake relative to its requirements could cause its $\mathrm{W}$ to deviate from its WM (above or below), and periods of severe nutritional stress could cause some reduction in WM growth (stunting). Present nutritional status of the animal was a function of its nutritional requirements, as determined by age, sex, size, condition, pregnancy, and lactational status and the quality and availability of feed and was reflected by growth of WM and change in W.

Milk production was calculated in a manner analogous to the calculation of growth rate. Genetic potential for milk production was specified for a mature cow in good condition at peak lactation 
receiving abundant feed. The effects of age, stage of lactation, condition, and nutrition determined actual production.

The basic nutritional concepts functioned as follows: (1) feed intake and potential performance were calculated based upon an animal's breedtype, age, WM, W, pregnancy status, and lactational status; (2) if the simulated nutrient intake was not adequate to meet the potential performance, the performance was adjusted downward in a stepwise fa shion until intake and mobilized fat were adequate to meet this reduced performance; and (3) energy intake in excess of requirements was deposited as fat. This approach to nutritional effects allowed simulation of compensatory growth and storage of excess intake for later use.

The model was modified to allow for increased maintenance energy requirements due to cold stress. Maintenance requirements (M) were increased using an adjustment factor for cold stress (CSA) as follows:

$$
\begin{aligned}
\mathrm{M} & =\mathrm{M}(1.0+\mathrm{CSA}) \\
\mathrm{CSA} & =\mathrm{CS}(\mathrm{T}) \quad\left(\frac{\mathrm{FATP}}{\mathrm{FAT}}\right)^{4} \quad\left(\frac{\mathrm{WMA}}{\mathrm{WM}}\right)^{15}\left(\frac{\mathrm{W}}{\mathrm{W}+\mathrm{FW}}\right)^{10}
\end{aligned}
$$

The base cold stress correction (CS) was set at .03 for December, .10 for January, .5 for February, and .00 for other months. This factor was increased when body fat (FAT) was less than that of an animal in good condition (FATP) and decreased for the opposite case of animals that were excessively fat. CS was also increased for immature animals, based on degree of maturity (ratio of WM to WMA). CS was decreased in pregnant animals by the ratio of weight (W) to $W$ plus fetal weight (FW) to account for heat production associated with pregnancy. The coefficients for these

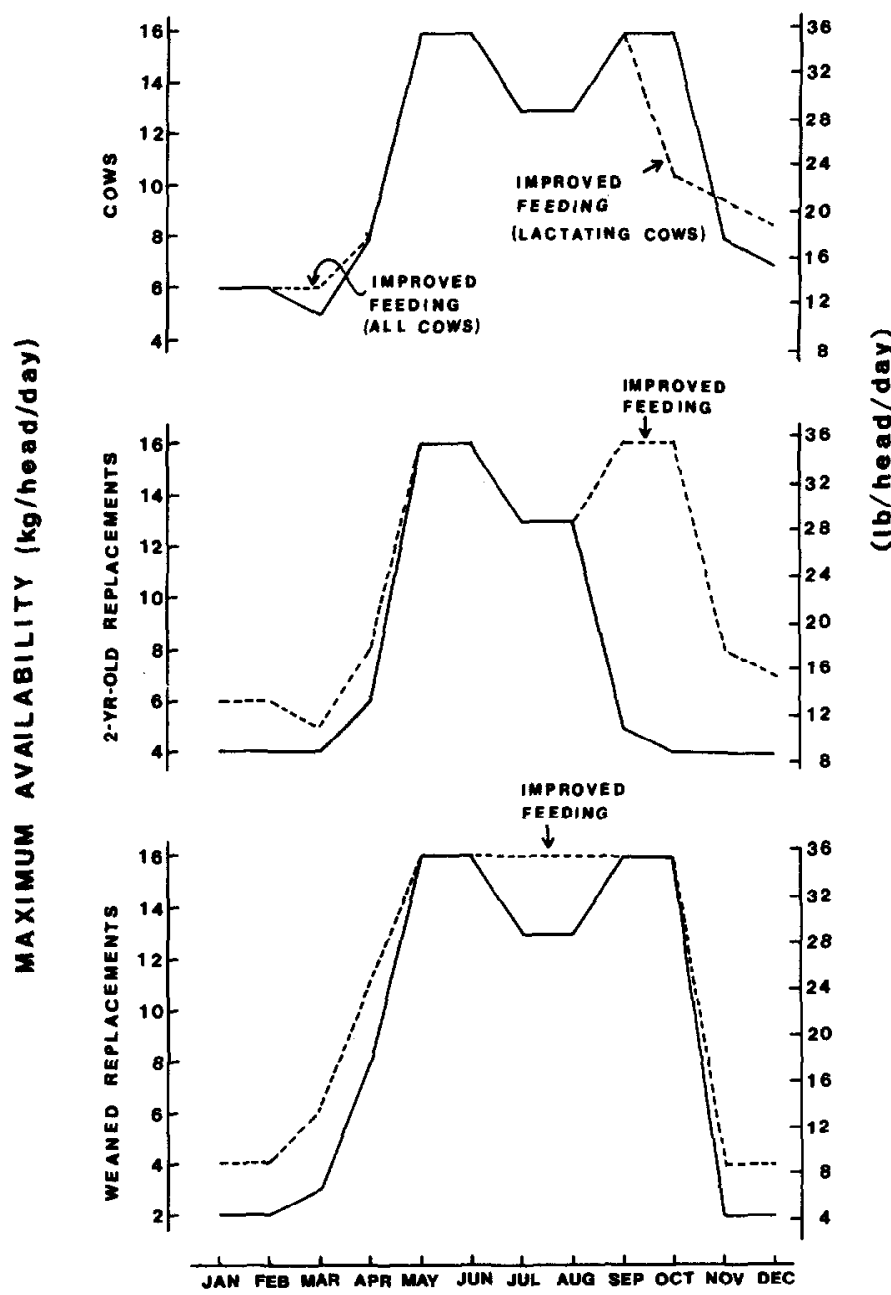

Fig. 1. Maximum availability of forage by month and class of stock for base (-) and improved (--.) nutritional treatments. adjustments were, by necessity, somewhat arbitrarily chosen; however, the adjustments were in the right direction and appeared to be of proper magnitude when compared to other methods of adjusting for cold stress (Young 1971).

The modification for cold stress was included because cow weights and calf weights simulated for January and February exceeded actual weights. This Coastal Prairie range generally had standing water on the ground during winter and little or no windbreak. Cows were thin, had low energy intake, had little or no chance to become acclimatized to cold, and had to lie on wet ground. These conditions resulted in considerable cold stress reflected in increased maintenance requirements. Inclusion of this modification resulted in better agreement between simulated and observed values of $W$.

A key component of the model was simulation of the effects of previous and present nutritional status on cow fertility (Sanders and Cartwright 1979a,b). This was done by setting maximum levels for the probability that (1) a female will begin to cycle (2) a cycling female will continue, and (3) a cycling female will conceive if mated. These maximum probability levels were adjusted downward for the following effects:degree of maturity (heifers only), condition, weight change, lactation, and postpartum interval for initiation of cycling; condition and weight change for the continuation of cycling; and condition, weight change, postpartum interval and adequacy of bulls for conception.

Death rates were predicted based upon time of year, condition, age, and parturition effects (cows and calves). In addition, death rates were increased in calves up to 4 mo of age that had reduced WM growth.

\section{Forage Parameters}

Nutritional management was simulated at two levels designated as
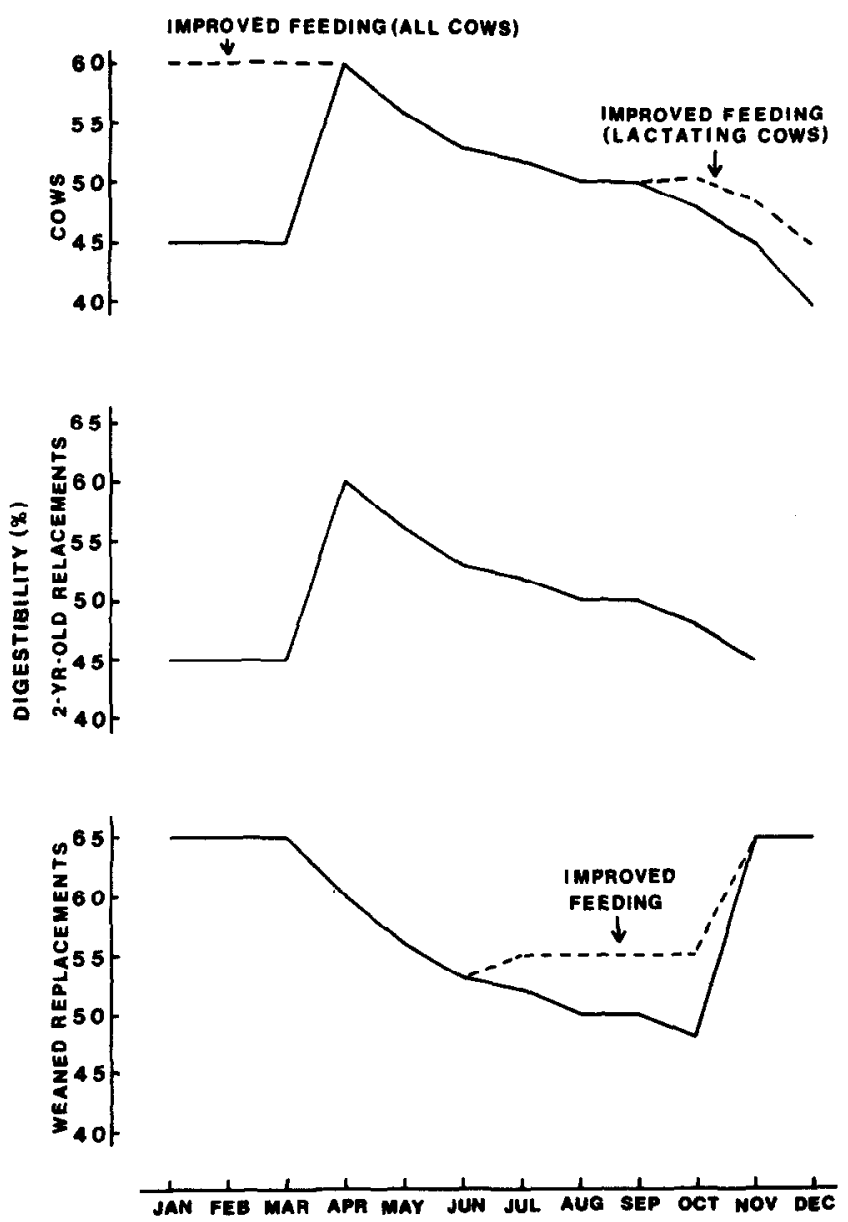

Fig. 2. Organic matter digestibility of forage by month and class of stock for base (-_) and improved (---) nutritional treatments. 

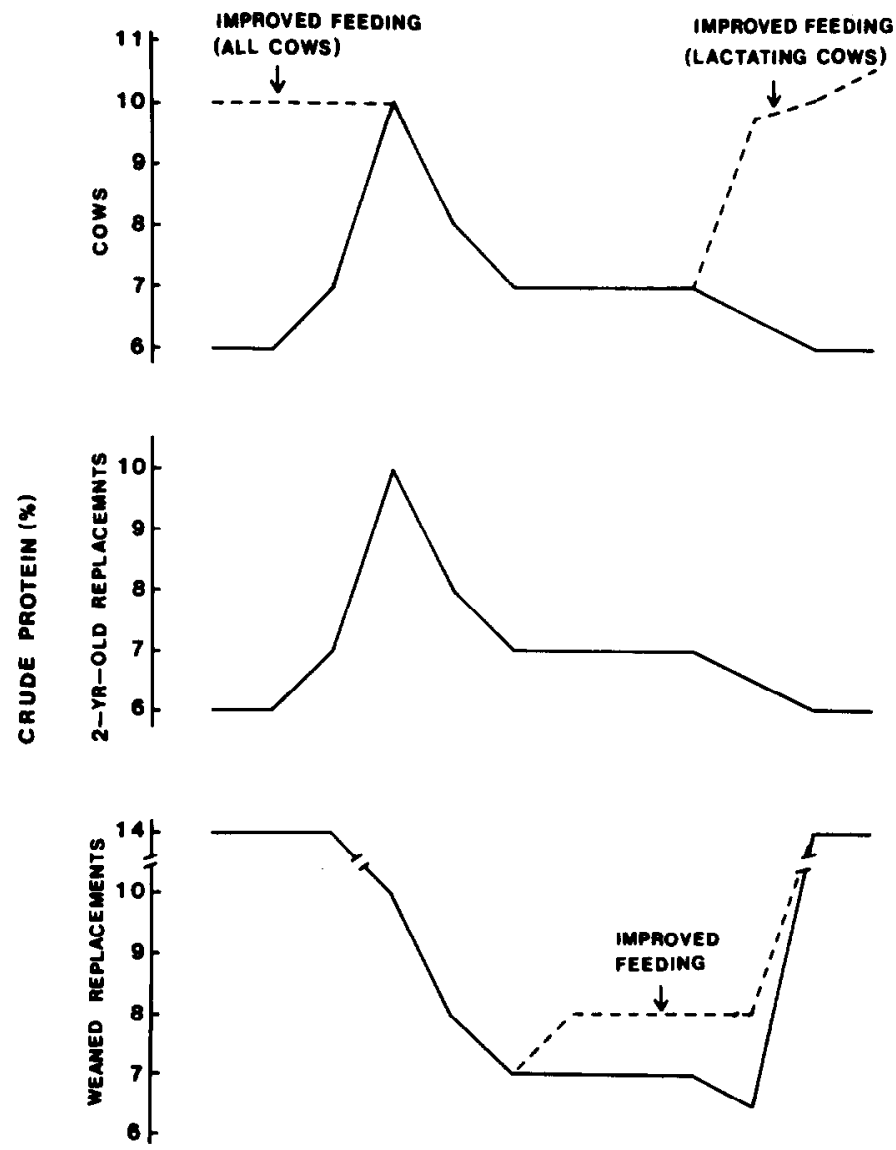

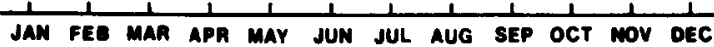

Fig. 3. Crude protein percentages offorage by month and class of stock for base (-) and improved (---) nutritional treatments.

base and improved. Stocking rate was held constant for this study; therefore, all treatment comparisons were made on herds of equal size and not on an a rea basis. Availability, CP content, and digestibility of forage were specified on a monthly time step for weaned replacement heifers, 2-year-old heifers, and cows (Fig. 1, 2, 3). When the simulated intake of forage exceeded the specified availability, intake was set equal to availability.

The values for availability, digestibility, and CP contents of forages (Fig. 1, 2, 3) were derived from published and unpublished research conducted on the ranch from 1974 to 1979 (Durham 1975 , Kothmann and Hinnant 1976, Durham and Kothmann 1977. Kothmann unpublished data). Many of the forage values were based on clipped forage analyses with only limited data from samples collected by esophageally fistulated animals (Durham 1975). The judgement and experience of the authors were used to extrapolate from clipped foragc analyses to estimated values for consumed forage. In the process of validation, simulated animal production was compared with actual animal production, and areas where there was significant lack of fit were evaluated to determine if changes in forage parameters might be justified.

Base nutritional management for weaned replacements consisted of range forage from weaning through October, then oat pasture from November through March, shifting to range forage in April Availability of oat pasture was restricted to adjust simulated heifer gains to actual gains. The oat pasture was not fertilized and was heavily stocked so that forage availability was the primary factor limiting gains. The improved nutritional management consisted of increased availability of oat pasture that allowed up to 4 $\mathrm{kg} \mathrm{D.M./head/day} \mathrm{intake,} \mathrm{with} \mathrm{CP} \mathrm{and} \mathrm{digestibility} \mathrm{unchanged.}$
For weaned replacements, improved nutritional management also included grazing on tame pasture from weaning through October. Availability of tame pasture and range were high enough not to limit intake during summer and early fall, but digestiblity and $C P$ were higher for tame pasture than for range. This improvement was partially confounded with the times of calving and weaning since fall calves weaned in July were on tame pasture longest. Winter and spring calves weaned October 1 had only 1 month on tame pasture prior to entering the oat pasture.

Weaned replacements were transferred to the 2-year-old category in July and remained in that category for 1 year. On the base nutritional level, Coastal bermuda hay was fed during January and February to the 2-year-old replacements at the rate of $4 \mathrm{~kg}$ D.M./ head/day with range forage providing the total diet for the remaining months. There was some difficulty in simulating actual gains of 2-year-old heifers until availability was restricted during the periods of September to December and March to April. The model calculated animal gains on the basis of energy intake, and during these periods protein availability probably limited animal growth. Another possible reason that actual gains were lower than simulated gains was reduced intake because of teeth shedding. Improved feeding of 2-year-olds consisted of increasing the level of Coastal bermudagrass hay from 4 to $6 \mathrm{~kg} \mathrm{D.M.} \mathrm{head/day} \mathrm{in}$ January and February and increasing the availability of range forage to the same levels allowed for the cows on base nutrition.

Base nutritional level for the cows ( 3 to 10 years of age) consisted of Coastal bermudagrass hay fed at the rate of $6 \mathrm{~kg} \mathrm{D.M./head}$ /day in January and February with grazed forage for the remainder of the year. Availability was set at levels which potentially restricted intake during March, April, November, and December. These restrictions were based on the assumption that availability of forage of the designated digestibility and $C P$ content was limited, although additional forage of lower nutrient content was available. Improved nutrition of cows consisted of sorghum hay for the three months of January, February, and March at the rate of $6 \mathrm{~kg} \mathrm{D.M./head/day} \mathrm{(Fig.} \mathrm{I).} \mathrm{Digestibility} \mathrm{of} \mathrm{the} \mathrm{sorghum}$ hay was $60 \%$ and $C P$ content was $10 \%$ (Fig. 2,3). Under improved nutrition, urea-molasses was fed at the rate of $1.5 \mathrm{~kg} / \mathrm{head} / \mathrm{day}$ to all fall-calving cows during October, November, and December and to winter-calving cows during December. The model did not provide for direct specification of separate supplement and forage parameters. For this reason, the urea-molasses supplementation was simulated by externally calculating parameters for a combined diet. Availability was adjusted by first simulating grazed forage intake without supplement, then the $1.5 \mathrm{~kg}$ of supplement was added to the simulated dry matter intake of forage and this value was set as the maximum availability.

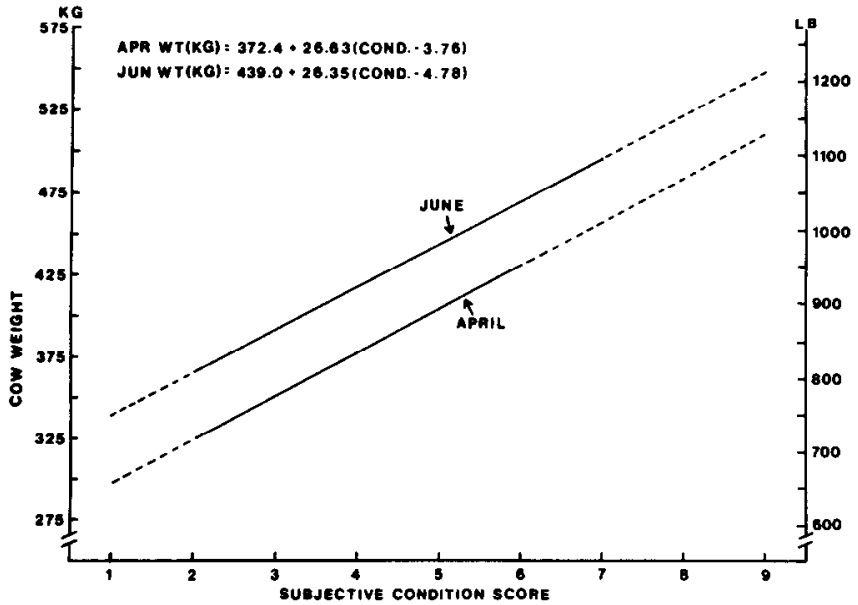

Fig. 4. Actual cow weights taken in April and June, 1979, regressed on subjective condition scores (_ actual data range, - - - extrapolated from data). 


\section{Cattle Parameters}

Breedtype was specified in terms of genetic potential for mature size, milk production, and maturing rate. The cattle parameters in the present study were chosen to represent a herd of grade Santa Gertrudis, but the results are directly applicable to other adapted breeds of similar size and milking ability.

Mature weight (WMA) was set at $500 \mathrm{~kg}$ based on indvidual weights, and condition scores taken on 200 cows in mid-April and again in mid-June, 1979 (Fig. 4). The mean weights and condition scores (scale of 1 to 9) are $372 \mathrm{~kg}$ and 3.76 units in April and $439 \mathrm{~kg}$ and 4.78 units in June. The relationship between weight and condition for each month was similar. The $67 \mathrm{~kg}$ difference between April and June weights at similar condition scores was attributed to increased fill. WMA represented the weight of mature cows in good condition; hence, the weight for a condition score of about 7 was selected.

Milk production potential was set at $11.5 \mathrm{~kg} /$ day, which is $15 \%$ higher than what has been used in previous simulations for the average of Hereford and Angus cows. This percentage increase was in line with preweaning growth rate differences of about $18 \%$ for Santa Gertrudis versus the average of Hereford and Angus calves at the McGregor Research Center (Miquel 1972) when allowance was made for increased growth potential of the Santa Gertrudis calves (U.S. MARC 1977).

In addition to the major specifications associated with breedtype, three other parameters were altered from those normally used for British breedtypes to better reflect the Zebu component. The fraction of mature size at which puberty could first occur was increased from 40 to $50 \%$ and the upper limit for this fraction to affect puberty was increased from 60 to $70 \%$. Also, preweaning and postweaning maturing rates were reduced.

\section{Cattle Management Alternatives}

Alternatives available to a ranch manager to help synchronize herd feed requirements with feed availability and quality include selection of calving season, weaning age, and heifer development rate. These factors interact with environmental effects, seasonal price fluctuations, and supplemental feeding practices. The cooperating ranch in this study calved from December through March and weaned in late September or early October. Heifers were developed to calve first at 3 years of age and only limited culling of cows was practiced.

Alternatives that were evaluated include winter, spring, fall and split (spring and fall) calving seasons. These were examined fortwo nutrition programs as outlined in the section on forage parameters. All comparisons were made for herds in equilibrium. That is, the management practices in question were continued until herd composition and productivity stabilized.

\section{Results and Discussion}

\section{Validation}

Animal performance and forage data from the cooperating ranch were used to verify that the input parameters and model structure closely simulated existing conditions. After the validation run was accepted, it was set as the baseline for comparison of management alternatives.

The correspondence between actual and simulated seasonal weight changes of mature cows is shown in Figure 5. The seasonal patterns of change for simulated and actual cow weights corresponded closely, but the magnitude of annual weight fluctuation was less for simulated data. The greater change for actual weight was attributed to differences in gut fill not accounted for by the model assumption of constant fill and was similar in magnitude to the $67 \mathrm{~kg}$ difference observed between April and June for cows in similar condition. The cows were very gaunt in early spring after the low level of winter hay feeding had been discontinued and before adequate spring growth of grass was available. On the other hand, the high availability of low quality forage resulted in nearcapacity rumen fill in the fall. In addition, lean tissue loss resulting from protein deficiency was not accounted for in the model and

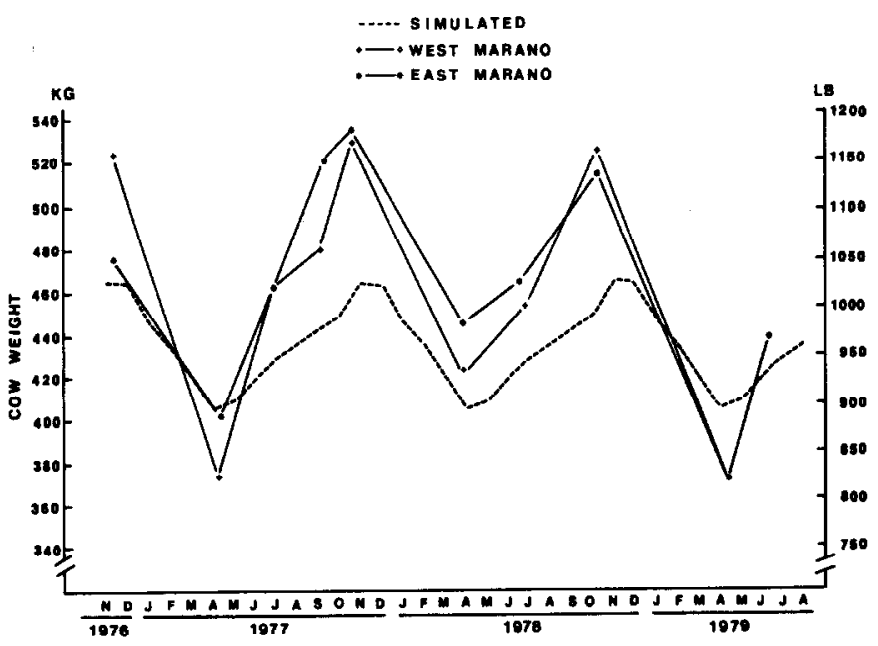

Fig. 5. Actual and simulated seasonal changes in mature cow weights.

may further explain why actual weights were less than simulated weights in the spring. The difference in magnitude of fluctuation between actual and simulated cow weights was not considered an important limitation to this study.

Simulated WM and W for replacement females from weaning through maturity along with a number of actual weights are shown in Figure 6. The actual weights were from a number of different pastures and years; hence, the lack of exact correspondence was not surprising. Except for the reduced magnitude of animal fluctuation discussed above, the correspondence between the actual and simulated data was considered good.

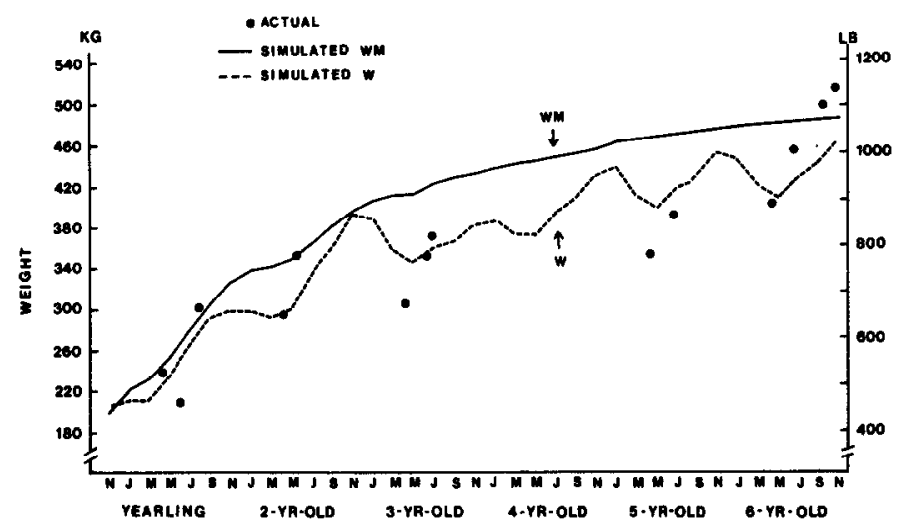

Fig. 6. Simulated structural size (WM), weight (W) growth curves and actual weights at different ages.

Comparisons of actual and simulated weights of nursing calves are shown in Figure 7 for birth months combined. Except for some yearly variation, the correspondence of weights near weaning was good. The model over estimated early spring weights, especially for calves born early in the calving season. This over estimation was considerably larger until the model was modified to increase maintenance requirements in young calves due to cold stress. The final simulation of preweaning weights was considered quite adequate.

Table 1. Actual weight (kg) and gain (kg/day) of 1977-born yearling heifers and baseline simulation.

\begin{tabular}{lcccccc}
\hline & Actual & & & \multicolumn{3}{c}{ Simulated } \\
\cline { 1 - 2 } Date & Weight & ADG & & Date & Weight & ADG \\
\hline $4 / 4 / 78$ & 240 & & & $4 / 1$ & 215 & \\
$7 / 29 / 78$ & 303 & & & $8 / 1$ & 279 & \\
\hline
\end{tabular}


Table 2. Calf deaths by year and pasture taken from ranch records.

\begin{tabular}{|c|c|c|c|c|}
\hline \multirow[b]{2}{*}{ Year } & \multirow[b]{2}{*}{ Pasture } & \multirow{2}{*}{$\begin{array}{l}\text { Born } \\
\text { No. }\end{array}$} & \multicolumn{2}{|c|}{ Died } \\
\hline & & & No. & $\%$ \\
\hline \multirow[t]{2}{*}{$74-75$} & $\begin{array}{l}\text { E. Marano } \\
\text { W. Marano }\end{array}$ & $\begin{array}{l}202 \\
220 \\
\end{array}$ & $\begin{array}{l}21 \\
18 \\
\end{array}$ & $\begin{array}{r}10.2 \\
8.2 \\
\end{array}$ \\
\hline & & 422 & 39 & 9.2 \\
\hline \multirow[t]{2}{*}{$76-77$} & $\begin{array}{l}\text { E. Marano } \\
\text { W. Marano }\end{array}$ & $\begin{array}{l}86 \\
56 \\
\end{array}$ & $\begin{array}{l}38 \\
17 \\
\end{array}$ & $\begin{array}{l}44.2 \\
30.4 \\
\end{array}$ \\
\hline & & 142 & 55 & 38.7 \\
\hline \multirow[t]{2}{*}{$77-78$} & $\begin{array}{l}\text { E. Marano } \\
\text { W. Marano } \\
\text { E. Big Past. } \\
\text { E. Humble } \\
\text { W. Sq. Tank }\end{array}$ & $\begin{array}{l}140 \\
129 \\
191 \\
208 \\
142 \\
\end{array}$ & $\begin{array}{l}36 \\
15 \\
18 \\
12 \\
15 \\
\end{array}$ & $\begin{array}{r}25.7 \\
11.6 \\
9.4 \\
6.3 \\
10.6 \\
\end{array}$ \\
\hline & & 810 & 97 & 12.0 \\
\hline
\end{tabular}

Simulated postweaning growth rate of yearling heifers was very similar to actual growth rate (Table 1). The heavier actual weights in this table were attributable to the 30 to $40 \%$ culling of light heifers; whereas, the simulated weights represented an average of all heifers.

Calf death rates by year and pasture are reported in Table 2 and summarized by birth month in Table 3. Large year and pasture differences resulted from major weather variations, extreme disease problems in one year, and differences in pasture drainage. The much higher death rates of December- and January-born calves (Table 3) reflected the stress of cold, wet winters and inadequate nutrition for lactating cows. The correspondence between actual and simulated death rates by birth month was excellent. Cow death rates were also highly variable among pastures and years but the simulated annual rate of $3.3 \%$ is identical to the 1978 ranch average of $3.3 \%$ (Table 4 ).

Simulated pregnancy percentage was somewhat higher than the 1978 palpation records averaged over all cow ages (Table 5). This difference was attributed to a fairly high incidence of brucellosis in the herd that was not accounted for by the model.

The high degree of correspondence between the baseline simulation and actual performance data was encouraging and suggested that useful comparisons of management alternatives can be made.

\section{Simulation of Management Alternatives}

Eight simulations of a $4 \times 2$ factorial design with 4 livestock management schemes and 2 levels of nutrition were evaluated. Only a limited amount of the simulation data generated by the model is reported in this paper. Primary emphasis has been placed on data that relate to calf production.

The percentage of cows becoming pregnant was affected more by changing nutritional level than by changing the time of calving

Table 3. Percentage of calves born by month and death rates by month of birth for actual data for the years 1977-78 and baseline simulation.

\begin{tabular}{|c|c|c|c|c|c|}
\hline \multirow[b]{2}{*}{ Source } & \multirow{2}{*}{$\begin{array}{l}\text { Birth } \\
\text { month }\end{array}$} & \multicolumn{2}{|c|}{ Born } & \multicolumn{2}{|c|}{ Died } \\
\hline & & No. & $T$ & No. & $\%$ \\
\hline \multirow[t]{5}{*}{ Actual } & Dec. & 337 & 24.5 & 62 & 18.4 \\
\hline & Jan. & 489 & 35.6 & 85 & 17.4 \\
\hline & Feb. & 236 & 17.2 & 21 & 8.9 \\
\hline & Mar. & 313 & 22.7 & 20 & 6.4 \\
\hline & & 1375 & 100.0 & 188 & 13.7 \\
\hline \multirow[t]{5}{*}{ Simulated } & Dec. & 199 & 44.2 & 28 & 14.1 \\
\hline & Jan. & 107 & 23.8 & 20 & 18.7 \\
\hline & Feb. & 79 & 17.6 & 9 & 11.4 \\
\hline & Mar. & 65 & 14.4 & 2 & 3.1 \\
\hline & & 450 & 100.0 & 59 & 13.1 \\
\hline
\end{tabular}

Table 4. Actual cow death rates (\%) for 4 herds in 1977 and 1978 and for the whole ranch in 1978 and baseline simulation for the whole ranch.

\begin{tabular}{lccc}
\hline \hline Herd & 1977 & 1978 & Simulated \\
\hline E. Marano & 10.8 & & \\
W. Marano & 8.5 & & \\
E. Big Past. & 18.8 & & \\
W. Big Past. & 5.9 & 4.5 & \\
$\quad$ Means & $\underline{12.8}$ & $\underline{2.6}$ & \\
Total Ranch1 & 12.1 & 6.0 & \\
\hline
\end{tabular}

'Total ranch included a number of other herds.

and weaning (Fig. 8). The percentage of cows pregnant with spring calving and split calving was greater than for fall or winter calving. It should be noted that fall calving was limited to a 3-month period while winter and spring calving were 4-month periods. Split calving consisted of 3-month calving periods during fall and spring with cows allowed to shift from one season to the other. In addition, spring calving cows nursed for 2 months less than fall and winter calving cows. The highest pregnancy rate was $83 \%$ for split calving under improved nutrition. No interaction between level of nutrition and calving season was apparent for pregnancy rate.

Level of nutrition interacted strongly with calving sea son with respect to calf mortality (Fig. 9). Calf mortality was much greater under the base nutrition with winter calving than under any other management alternative. This high mortality rate was reduced by improving nutrition or by changing the calving season. The highest mortality rates always resulted from over-wintering young calves. There appeared to be little opportunity for additional reduction of death losses by further improvement in nutrition.

The number of calves sold per 1000 cows was lowest for winter calving and highest for split calving (Fig. 10). Improved nutrition had a significant effect on calves sold from all management systems, with the greatest effect found in winter calving. The differences among calving and weaning alternatives were greater under base nutrition than under improved nutrition.

Level of nutrition affected weaning weights differently depending on the season of calving (Fig. 11). The younger spring-born calves were lightest under base and improved nutrition and they exhibited the least spread between levels of nutrition. Fall and winter calves had comparable weaning weights on base nutrition, but with improved nutrition fall calves were heavier than winter

Table S. Actual pregnancy data age class and baseline simulation.

\begin{tabular}{llcc}
\hline Herd & Age & No. & $\begin{array}{c}\text { Pregnancy \% } \\
1978\end{array}$ \\
\hline E. Marano & 7,8 & 187 & 63 \\
W. Marano & 6,7 & 191 & 58 \\
E. Big Past. & $6,7,8$ & 229 & 52 \\
W. Big Past. & $5,6,7,8$ & 225 & $82^{1}$ \\
E. Humble & 6,7 & 217 & 51 \\
W. Humble & $4,5,6$ & 223 & $82^{1}$ \\
E. Sq. Tank & 3,4 & 201 & 42 \\
W. Sq. Tank & 3,4 & 216 & 60 \\
\multicolumn{1}{c}{ Mean } & & & 61.3
\end{tabular}

\begin{tabular}{rr}
\multicolumn{2}{c}{ Simulation } \\
\hline 3 & 85.3 \\
4 & 60.8 \\
5 & 64.5 \\
6 & 62.4 \\
7 & 69.2 \\
8 & 63.8 \\
9 & 65.3 \\
10 & 62.0 \\
\hline
\end{tabular}

'All cows dry during 1978. 


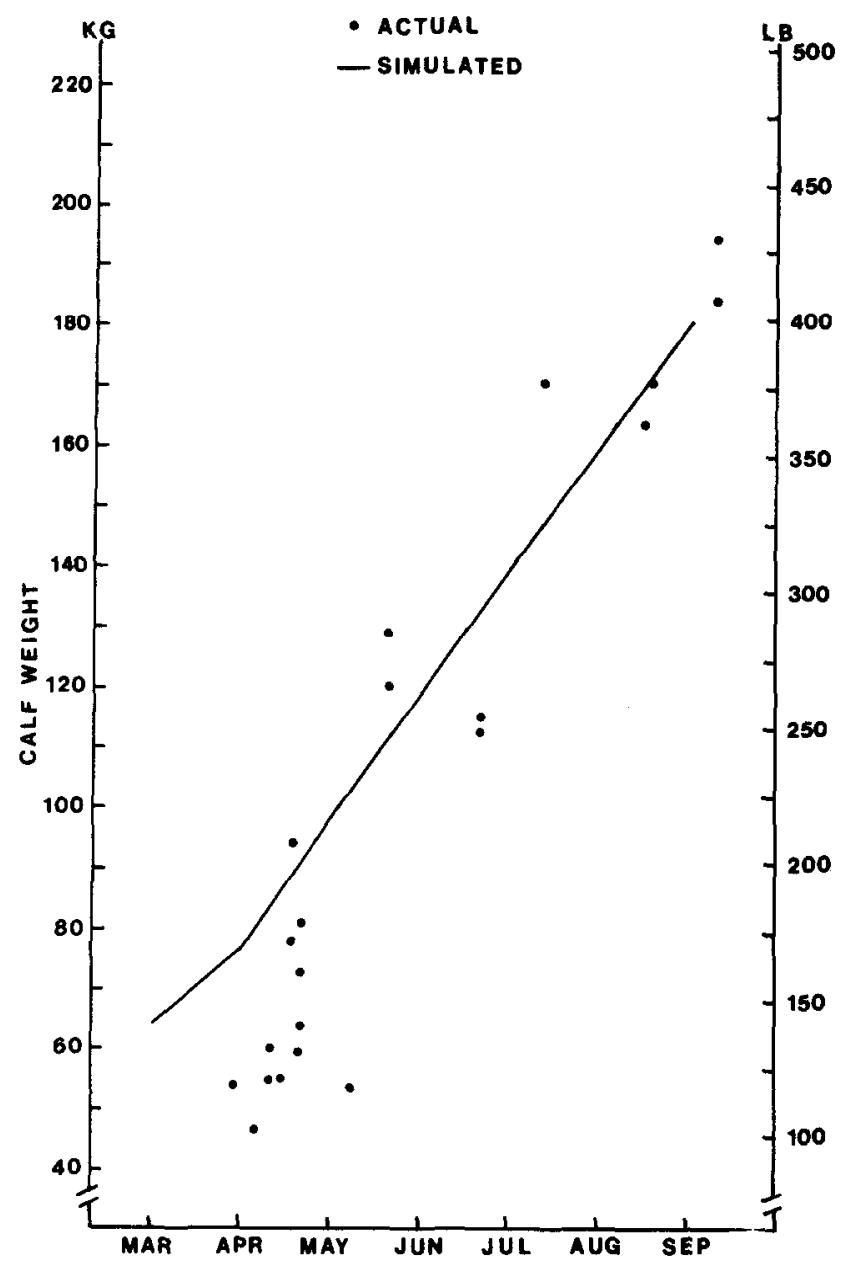

Fig. 7. Actual and simulated preweaning calf weights averaged across months.

calves. Spring calves had little opportunity to utilize the higher quality forage available during spring; whereas, fall and winter calves were old enough to utilize this forage. Fall calves received the greatest benefit from improved winter nutrition because of the

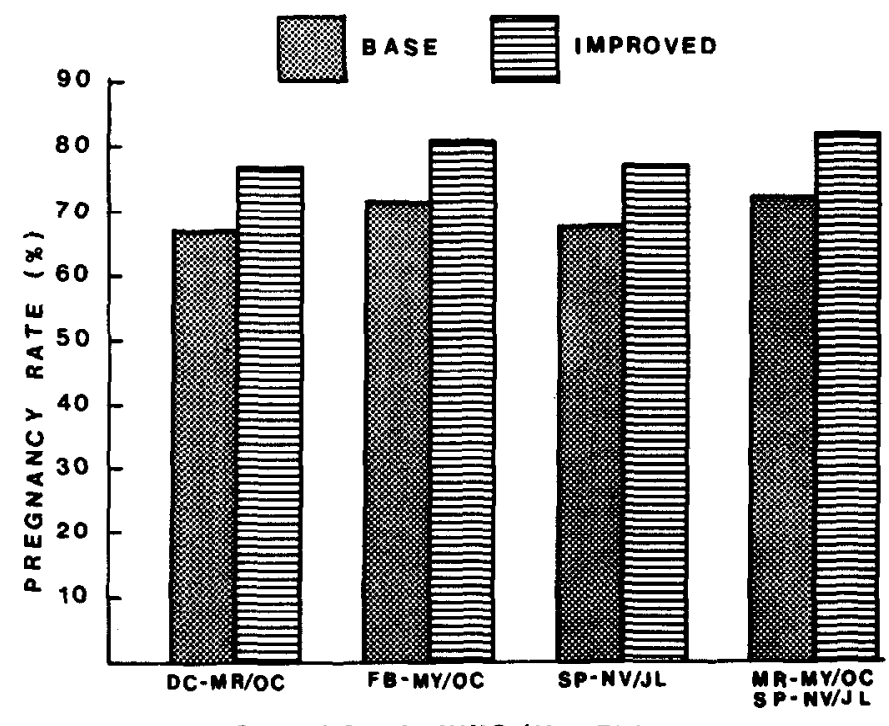

CALVING/WEANING (MONTH)

Fig. 8. Simulated percentages pregnant of cows exposed to breeding for four calving season/weaning age options and 2 levels of supplemental feeding.

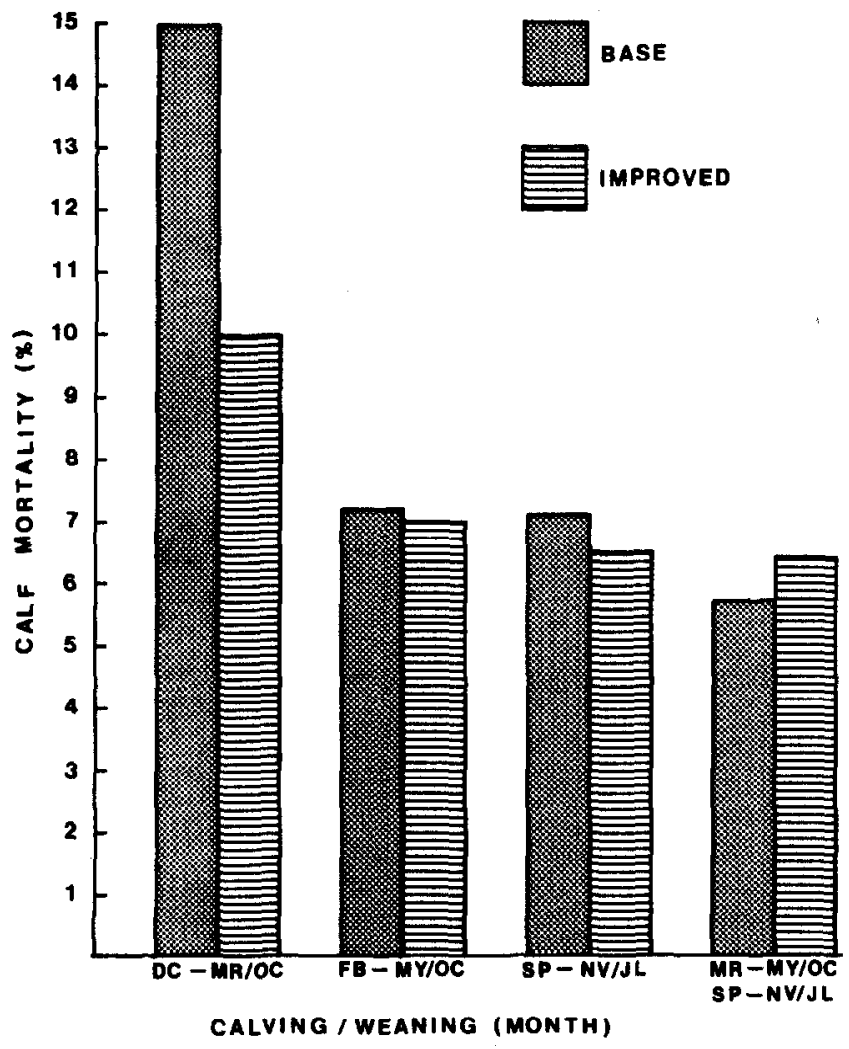

Fig. 9. Simulated preweaning calf mortality for 4 calving season/weaning age options and two levels of supplemental feeding.

increased milk production of their dams.

The weight of calves and weight of cull cows sold on a per cow ( 1 year of age and older) basis was considered to be a significant measure of production from the different management alternatives simulated. The weight of cull cows sold was essentially the same for all management practices (Fig. 12). However, weight of calf sold differed markedly among treatments. Winter calving with base

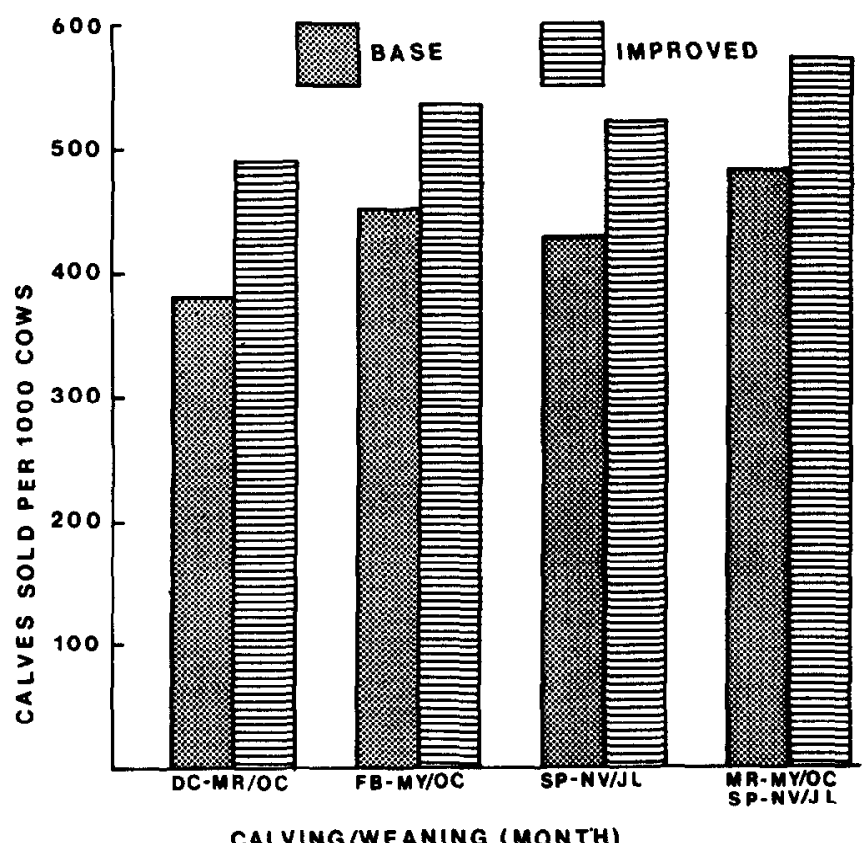

Fig. 10. Simulated calves sold per 1000 cows (one year of age and older) from 4 calving season/weaning age options and 2 levels of supplemental feeding. 


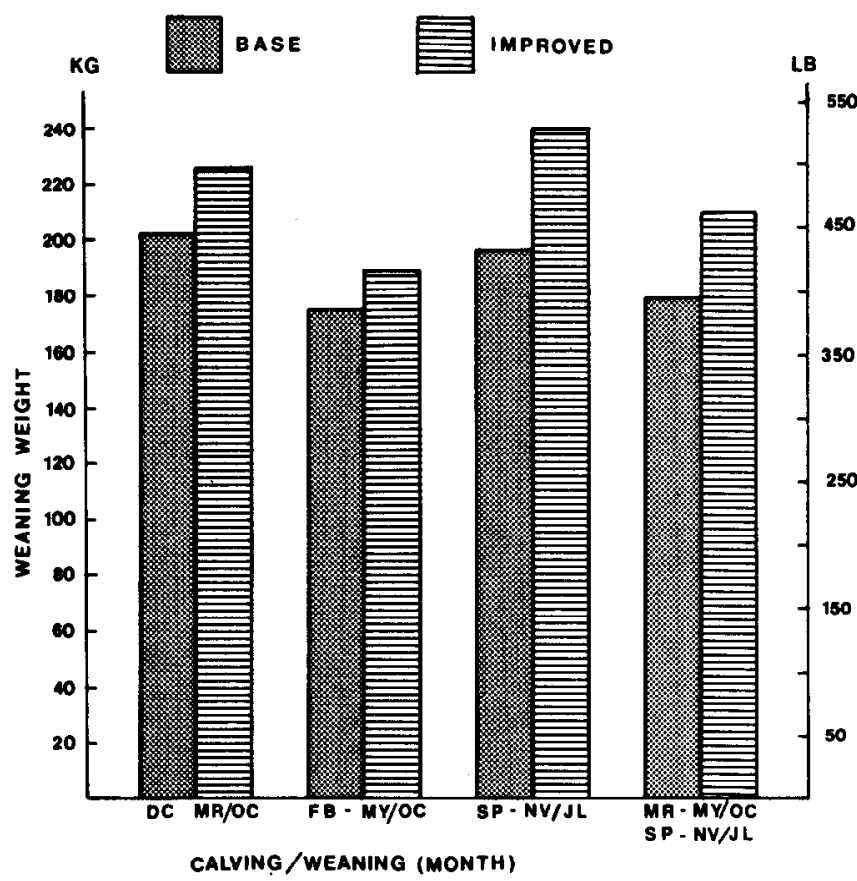

Fig. 11. Simulated weaning weights of calves for 4 calving season/weaning age options and 2 levels of supplemental feeding.

nutrition was lowest and fall calving with improved nutrition was highest. Changing calving from winter to fall under base nutrition increased calf sold per cow by $8 \mathrm{~kg}$; under improved nutrition, the increase was $15 \mathrm{~kg}$ (Fig. 12). Improved nutrition had a greater effect on calf production than did calving season. The response to improved nutrition varied from $42 \mathrm{~kg}$ under fall calving to $22 \mathrm{~kg}$ under spring calving with winter and split calving being intermediate (Fig. 12).

Based upon the simulations reported here, different management strategies may be formulated. For a rancher desiring the lowest cash imput with a maximum number of calves produced, spring calving or split calving appear most effective; however, weaning weights would be reduced. Simulations suggested that high levels of supplements had less effect on these management alternatives because weaning weights of spring calves showed little response to improved nutrition. For a rancher desiring to increase calf weights, fall calving appeared to offer the best opportunity, primarily because weaning weight of fall calves responded well to improved nutrition. However, fall calving required greater expenditures for feed, and early fall feeding would be essential to assure good conception rates.

Full interpretation of these data requires that economic aspects of the practices be considered. Simulations were run for numerous different management alternatives. Results of this more extensive study and economic analysis of all the treatments will be reported in subsequent publications.

\section{Research Needs}

Field research is very limited for production schemes involving several different management alternatives. Because of limited availability of resources (money, land, personnel, and time) and difficulties in designing such studies, most research has been directed towards comparison of a few management practices involving only one segment of the production scheme. Ranchers must select and combine management practices for all phases of production programs with little guidance from research with respect to possible interactions of these practices when combined in an integrated management program. Systems research may assist both the producer and the researcher by allowing evaluation of integrated production systems. A variety of alternatives can be examined providing a basis for producers to make management decisions.

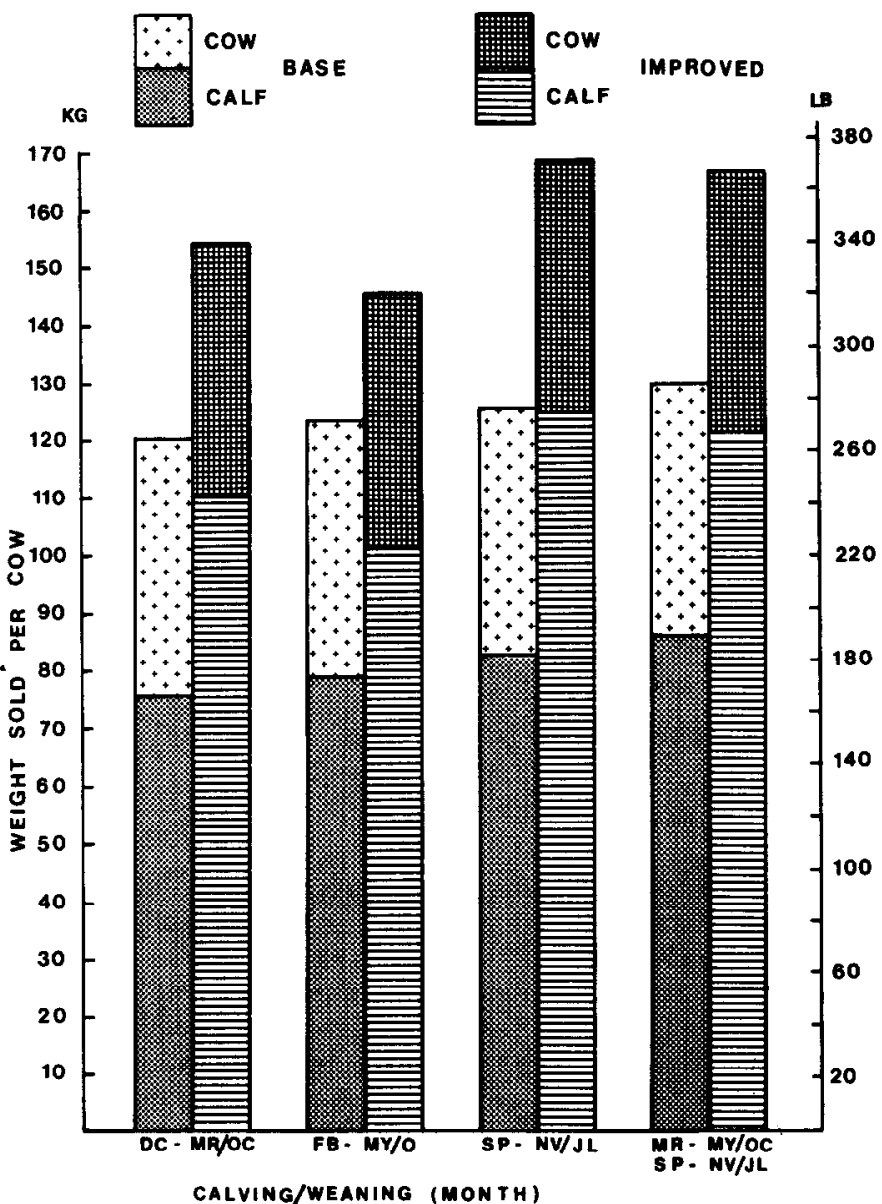

Fig. 12. Simulated calf weight and cow weight sold per cow (1 year of age and older) for 4 calving season/weaning age options and 2 levels of supplemental feeding.

The present cattle model is adequate for evaluating management alternatives when forage quality and availability data are present for the different alternatives. This capability can be used to greatly reduce the cost of grazing management research. Herd productivity can be predicted by simulation rather than by using the large numbers of livestock necessary to measure it directly. However, there is a critical need to develop plant/animal interface models that will accurately predict availability and quality for forage and nutrient intake of grazing animals for different range and livestock management schemes. Efforts to develop these grazing models to link current animal and plant models are underway at some locations (HFRO 1979, Tadmor et al. 1977), but deserve increased attention by others involved in integrated animal and range research.

\section{Literature Cited}

Baker, J.F. 1982. Evaluation of genotype-environment interactions in beef cattle production systems using a computer simulation model. Ph.D. Thesis, Texas A\&M Univ., College Station.

Durham, Albert J., Jr. 1975. The botanical and nutritive composition of winter diets of cattle grazing prairie on the Texas Gulf Coast. M.S. Thesis, Texas A\&M Univ., College Station.

Durham, Albert J., Jr., and M.M. Kothmann. 1977. Forage availability and cattle diets on the Texas Coastal Prairie. J. Range Manage. 30:103-106.

HFRO. 1970. Science and Hill Farming. HFRO 1954-1979. Hill Farming Research Organization. Scotland.

Kothmann, M.M., and R.T. Hinnant. 1976. Winter nutrition for cow-calf production in the Coastal Prairie. Proc., Soc. Range Manage. Meeting, Omaha, Neb. (Abstract). 
Miquel, C.M. 1972. Influence of dam weight on her productivity. Ph.D. Dissertation, Texas A\&M Univ., College Station.

NRC. 1970. Nutrient requirements of beef cattle. Nat. Acd. Sci., Nat. Res. Council. Washington, D.C.

Sanders, J.0.1974. A model of reproductive performance in bovine female. M.S. Thesis, Texas A\&M Univ., College Station.

Sanders, J.0. 1977. Application of a beef cattle production model to the evaluation of genetic selection criteria. Ph.D. Diss., Texas A\&M Univ., College Station.

Sanders, J.O., and T.C. Cartwright. 1979a. A general cattle production systems model. I. Structure of the model. Agr. Systems 4:217-227.
Sanders, J.0., and T.C. Cartwright. 1979b. A general cattle production systems model. Il. Procedures used for simulating animal performance. Agr. Systems 4:289-309.

Tadmor, N., I. Noy-Meir, U. Safriel, N. Seliginan, A. Goldman, J.K. Katznelson, E. Eyal, and R. Benjamin. 1977. A simulation model of a semiarid Mediterranean grazing system, Israel J. of Bot. 26:161-171.

U.S. Meat Animal Research Center. 1977. Germ Plasm Evaluation Program. Prog. Rep. No. 5. ARS-NC-55.

Young, B.A. 1971. Practical means for estimating cold stress in cattle. 50th Feeders' Day Rep. Univ. Alberta. Edmonton. p. 12-14. 